\title{
MENINGKATKAN KEMAMPUAN GURU SDN NO. 157617 PINANGSORI 13 DALAM MELAKSANAKAN STRATEGI PEMBELAJARAN CTL MELALUI SUPERVISI KELAS TAHUN PELAJARAN 2017/2018
}

\author{
Heldina Sihotang
}

Kepala SDN 157617 Pinangsori 13

\begin{abstract}
Abstrak
Tujuan dalam penelitian ini adalah untuk mengetahui peningkatkan kemampuan guru dalam melaksanakan strategi pembelajaran CTL melalui kegiatan supervisi kelas. Penelitian ini dilakukan di SDN 157617 Pinangsori 13 dengan obyek penelitian adalah guru berjumlah 9 orang pada tahun pelajaran 2017/2018 menggunakan desain penelitian tindakan sekolah dengan dua siklus melalui empat tahapan masing-masing siklus yaitu perencanaan, pelaksanaan, observasi dan refleksi. Pengumpulan data dilakukan melalui observasi, tes hasil belajar. Hasil penelitian menunjukkan melalui supervisi kelas dapat meningkatkan kemampuan guru dalam menerapkan strategi pembelajaran Contectual Teaching and Learning (CTL) di SDN 157617 Pinangsori 13, Pelaksanaan Supervisi Kelas oleh Kepala Sekolah dapat meningkatkan aktivitas, motivasi dan kreatifitas guru untuk melaksanakan inovasi pembelajaran.
\end{abstract}

Kata Kunci: Kemampuan Guru, CTL, Supervisi Kelas

\section{Pendahuluan}

Kepala sekolah adalah guru yang diberi tugas tambahan untuk memimpin sekolah yang tugas pokok dan fungsinya mempunyai peran ganda dalam menentukan mutu pendidikan (bahkan sebagai penjamin mutu pendidikan, pembina para guru, serta penentu professional tidaknya para kepala sekolah disekolah ditempat dia bertugas sebagai kepala sekolah), kepala sekolah sebagai supervisor akademik dan manajer. Supervisi kelas lebih dominan dilaksanakan oleh Kepala Sekolah dalam Proses Belajar
Mengajar (PBM) oleh tenaga kependidikan baik dalam kelas maupun diluar kelas.

Oleh sebab itu terdapat hubungan yang saling menguntungkan (resivokal) bagi guru dan kepala sekolah, karena sudah merupakan tugas kepala sekolah dalam menyukseskan program terlaksanaanya strategi pembelajaran CTL untuk meningkatkan kompetensi guru.

Pembelajaran kontekstual CTL adalah konsep belajar yang membantu guru mengaitkan antara materi yang diajarkan dengan situasi dunia nyata siswa dan 
mendorong siswa membuat hubungan antara pengetahuan yang dimilikinya dengan penerapannya dalam kehidupan mereka sehari - hari, dengan melibatkan tujuh komponen utama pembelajaran efektif, yaitu : Kontruktifisme, bertanya, menemukan, masyarakat belajar, pemodelan, refleksi dan penilaian sebenarnya. Strategi pembelajaran CTL, belajar tidak hanya sekedar menghapal, melainkan siswa harus mengkonstruksikan pengetahuan dibenak mereka sendiri, anak belajar dari mengalami, anak mencatat sendiri pola pola bermakna dari pengetahuan baru, dan bukan diberi begitu saja oleh guru. Manusia mempunyai kecenderungan untuk belajar dalam bidang tertentu, dan seorang anak mempunyai kecenderungan untuk belajar dengan cepat mengenai hal hal baru.

Disamping itu sesuai dengan peraturan Menteri Pendidikan Nasional Nomor 12 Tahun 2007 tentang standar kompetensi Kepala sekolah / Madrasah, dinyatakan bahwa Kompetensi Kepala Sekolah SD, SMP/SMA harus memiliki lima dimensi kompetensi, yaituKompetensi Kepribadian, kompetensi pengelolaan pembelajaran, Kompetensi supervisi Kelas, Kompetensi Evaluasi Pendidikan, dan Kompetensi Sosial.

\section{Dalam dimensi kompetensi Supervisi} Kelas, kepala sekolah harus menguasai berbagai macam teknik supervisi dan mampu membimbing guru dalam pembelajaran. Sejalan dengan kompetensi dan tugas Kepala Sekolah yang tertera diatas, maka Kepala Sekolah memiliki tugas dan tanggung jawab untuk membimbing guru dalam memilih dan menggunakan strategi/pendekatan pembelajaran yang dapat mengembangkan berbagai potensi siswa. Hal ini penting terutama untuk menciptakan iklim pembelajaran yang kondusif dan menyenangkan.

Agar semua guru memiliki kompetensi dan professional dalam menggunakan pendekatan pembelajaran CTL, maka Kepala Sekolah hendaknya melaksanakan tugas supervisi kelasnya secara rutin, tertib dan terencana.

Mulyana (2004 : 88) menyatakan bahwa Kepala sekolah dalam melaksanakan tugas supervisi akademik harus memiliki program kegiatan untuk : memberikan arahan dan bimbingan kepada guru tentang pelaksanaan pembelajaran, memberikan contoh tugas guru bimbingan peserta didik, melaksanakn kunjungan kelas, memberikan lpaoran tentang peningkatan kemampuan professional guru kepada Kepala Sekolah dan instansi terkait.

Berbagai kendala dan kesulitan serta kekurangan profesionalan guru dalam melaksanakan tugas pembelajarannya disekolah, akan dapat diatasi manakala para kepala sekolah melaksanakan tugas supervisi kelas dengan terprogram terarah dan terencana yang tidak kalah pentingnya kepala sekolah tersebut harus professional.

Contextual Teaching and Learning (CTL) adalah suatu strategi pembelajaran yang menekankan kepada proses keterlibatan siswa secara penuh untuk dapat menemukan materi yang dipelajari dan menghubungkannya dengan situasi kehidupan nyata sehingga mendorong siswa 
untuk menerapkannya dalam kehidupan mereka. (Sanjaya,2010 : 255)

Dengan menggunakan pendekatan kontekstual, maka pelajaran yang disampaikan akan lebih menarik minat para siswa dari pada pembelajaran yang hanya disampaikan dengan cara ceramah secara monoton ( konvensional). Sedangkan belajar yang disertai minat yang tinggi akan lebih baik hasilnya daripada belajar tanpa minat.

Srtategi pembelajaran CTL yang merupakan konsep pembelajaran yang menentukan pada keterkaitan antara materi pelajaran dengan dunia kehidupan peserta didik secara nyata, sehingga peserta didik mampu menghubungkan dan menerapkan kompetensi hasil belajar dalam kehidupan sehari - hari.

Mulyasa (2005 : 5) mengemukakan pentingnya lingkungan belajar dalam pembelajaran kontekstual sebagai berikut : 1) Didepan kelas, siswa monoton, kesiswa aktif bekerja dan berkarya, guru mengarahkan Pembelajaran harus berpusat pada bagaimana cara siswa menggunakan pengetahuan baru mereka. Strategi belajar lebih dipentingkan daripada hasilnya; 2) Umpan balik amat penting bagi siswa, yang bersal dari proses penilaian yang baru; 3) Menumbuhkan komunitas belajar dalam kelompok; 4) Semua guru harus memiliki kompetensi professional, yang salah satunya adalah professional dalam menggunakan CTL, maka kepala sekolah hendaknya melaksanakan tugas supervisi kelas secara rutin, terencana dan tertib.
Mulyasa (2005 : 75 ) menyatakan bahwa Kepala sekolah dalam melaksanakan tugas supervisi kelas harus memiliki program kegiatan untuk : memberikan arahan dan bimbingan kepada guru tentang pelaksanaan pembelajaran, memberikan contoh tugas guru bimbingan, melaksanakan kunjungan kelas, memberikan saran atas profesionalisme guru.

\section{Metode Penelitian}

Jenis penelitian ini adalah penelitian tindakan sekolah ( School Action Research) dengan dua siklus masing-masing siklus dengan tahapan perencanaan, pelaksanaan, yang dilakukan oleh kepala pengamatan dan reflksi. Lokasi penelitian ini adalah SDN 157617 Pinangsori 13 dengan jumlah responden 9 orang guru. Waktu penelitian ini berlangsung selama 3 bulan kalender dari bulan Juli 2017 s/d September 2017.

Alur kegiatan penelitian tindakaan kelas yang dilaakukan seperti pada gambar 1 di bawah.

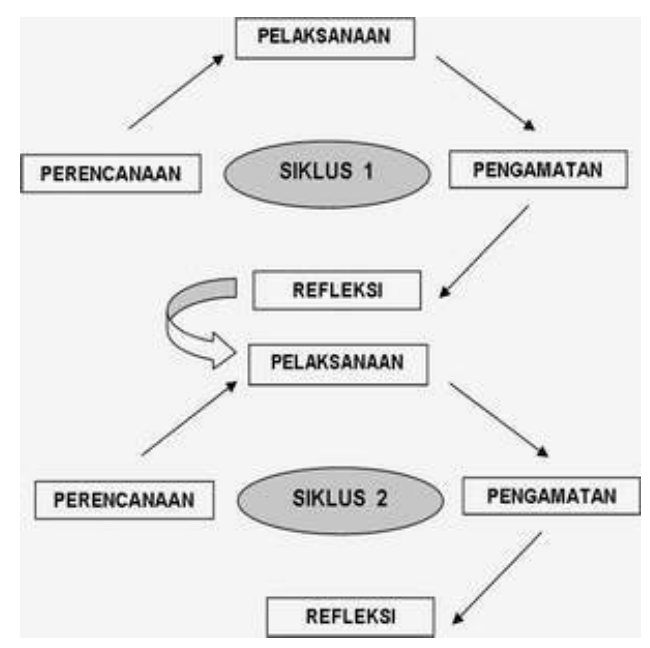


Pembahasan dan Hasil

Berdasarkan hasil Supervisi Kelas, penelitian dan pengamatan yang dilaksanakan di SDN 157617 Pinangsori 13 kabupaten Tapanuli Tengah selama 3 bulan untuk 8 kali pertemuan menunjukkan dari 9 guru, perhatian dan minat para guru dalam mengikuti dan menerima pembinaan Supervisi Kelas mengalami kenaikan dari siklus1 ke siklua 2 sebesar 33,3\%, menunjukkan penuh perhatian dan minat yang tinggi mengalami kenaikan dari siklus1 ke siklua 2 sebesar 11,1 \% para guru mengikuti kegiatan supervisi kelas dengan motiovasi sendiri mengalami kenaikan dari siklus1 ke siklua 2 sebesar 22,2\% dalam kegiatan pembinaan akademik oleh guru mampu memanfaatkan kegiatan tersebut untuk bertanya, menjawab dan memberikan tanggapan terhadap kegiatan supervisi yang dilaksanakan mengalami kenaikan dari siklus1 ke siklua 2 sebesar 22,2\% dan menutup pelajaran dengan baik mengalami kenaikan dari siklus1 ke siklua 2 sebesar $21,1 \%$.

Pembinaan pembelajaran yang dilaksanakan oleh Kepala Sekolah ternyata memberikan dorongan kepada guru untuk lebih kreatif dalam melaksanakan tugasnya. Adapun pengaruh pembinaan pembelajaran terhadap penguasaan dan pelaksanaan penggunaan strategi pembelajaran CTL ditunjukkan bahwa diatas 85\% menjawab "YA" dan selebihnya "TIDAK" pada setiap butir pertanyaan. Hal ini dapat ditapsirkan bahwa kegiatan belajar mengajar dengan menggunakan strategi pembelajaran CTL perlu dilaksanakan dan mereka (guru SDN 157617 Pinangsori 13 merasa lebih semangat dan termotivasi dalam melaksanakan tugas dan nantinya akan meningkatkan mutu pendidikan khususnya pada SDN 157617 Pinangsori.

\section{Kesimpulan}

Berdasarkan hasil penelitian dapat disimpulkan sebagai berikut :

1. Pelaksanaan Supervisi Kelas yang dilaksanakan oleh Kepala Sekolah di SDN 157617 Pinangsori 13 dapat meningkatkan kemampuan guru dalam melaksanakan strategi pembelajaran CTL sangat direspon oleh para guru dan memberikan pengaruh yang cukup besar terhadap kreatifitas guru dalam melaksanakan tugas kegiatan belajar mengajar didalam kelas.

2. Pelaksanaan Supervisi Kelas oleh Kepala Sekolah dapat meningkatkan aktivitas, motivasi dan kreatifitas guru terutama yang selama ini belum memiliki keberanian untuk melaksanakan inovasi pembelajaran.

\section{Saran}

Berdasarkan hasil belajar sebagaimana diuraikan diatas disampaikan saran sebagai berikut :

1. Kepala Sekolah hendaknya selalu berusaha untuk memberikan pembinaan akademik melalui supervisi kelas yang menekankan kepada pemberian kesempatan kepada guru untuk lebih banyak berinisiatif dan inovatif, dalam 
penggunaan strategi pembelajaran CTL pada proses pembelajaran

2. Perlu ada kerjasama sekolah dengan berbagai pihak seperti pengawas sekolah dan lainnya dalam pembinaan guru dalam pelaksanaan pembelajaran CTL.

3. Penelitian tindakan sekolah ini dilaksanakan dengan sangat sederhana, maka hendaknya hasil penelitian ini dijadikan tolak ukur ditindak lanjuti dengan pengkajian lebih mendalam.

\section{Daftar Pustaka}

Direktorat Tenaga Pendidikan, Dirjen PMTK Depdiknas, (2007). Petunjuk Teknis Penelitian Tindakan Sekolah. (School Action Research), Peningkatan Kompetensi Guru Kelas SMP / SMA, Jakarta.

Komaria, Aan dan Cepi Triana. (2004). Visionaruy Leadership Menuju Sekolah Efektif, Bandung Aksara.

Lie, Anita (2002). Coorperative Learning ( Menerapkan Coorperative Learning di ruang - ruang kelas). Jakarta : Gasindo

Mulyasa, E (2005). Menjadi Guru Kelas Profesional Menciptakan Pembelajaran Kreatif dan Menyenangkan. Bandung : Rosda Karya

Mulyasa, E (2005). Peran dan Kinerja Kepala Sekolah. Bandung : Rosda Karya.

Permendiknas No. 12 Tahun (2007).

Tentang Standar Kepala Sekolah / Madrasah.
Sanjaya, Wina. ( 2010) Strategi Pembelajaran Berorientasi Standar Proses Pendidikan Cetakan ke 7. Jakarta: Kencana 